\title{
Fecal microbiota transplantation capsule therapy via oral route for combatting atopic dermatitis in dogs
}

\author{
Kerem URAL \\ Aydın Adnan Menderes University, Faculty of Veterinary Medicine, Department of Internal Medicine, Aydın, TURKEY \\ ORCID: 0000-0003-1867-7143 \\ Corresponding author: uralkerem@gmail.com \\ Received date: 08.11.2020 - Accepted date: 17.06.2021
}

\begin{abstract}
Given the role of the interaction between gut microbiome with dermatological diseases, namely "gut-skin axis", the present author proved that gut restoration should alleviate canine atopic dermatitis (CAD), which was the purpose of the study. A 4 week, open-label, non-controlled case series involved 8 -owned dogs with CAD which had received no previous treatment. Evaluations included Canine Atopic Dermatitis Extent and Severity Index version 4 (CADESI-04 scores), Visual Analog Scale (VAS) pruritus scores and Polycheck in vitro allergen specific tests. Faecal samples were analysed by dual indexing one-step PCR and 16S rRNA targeted metagenomics for detecting gut microbiota alterations before and after fecal microbiota transplantation (FMT) capsule treatment twice daily for 4 weeks. All cases were presenting pruritus and all of those dogs showed elevated IgE levels. CADESI scores decreased on days 28 (4-21) compared to day 0 initial values (50-128). Similarly, decreased VAS scores were detected on days 28 (02 ) in contrast to prior values (6-10). Regarding epidermal barrier functioning epidermal hydration (55-100 vs. 4-24) and pH (6.-7.8 vs. 4.2-5.7) values were elevated after FMT treatment in contrast to prior ranges, respectively. Alpha diversity revaled both richness and diversity of gut microbiota were improved for all cases on day 28. Furthermore at the end of trial Firmicutes: Bacteroidetes ratio was $<8$, the benchmark detected for healthy dogs. The present study supports a potential benefit of FMT capsule treatment against CAD. This safe and tolerant treatment modality directed against CAD shifted the gut microbiome composition towards a healthy state for all 8 dogs enrolled.
\end{abstract}

Keywords: Atopic dermatitis, dog, fecal microbiota transplantation.

\section{Köpeklerde atopik dermatitisle mücadelede oral yolla fekal mikrobiyota transplantasyon kapsül sağaltımı}

Özet: Bağırsak mikrobiyomu ile dermatolojik bozukluklar arasındaki ilişki göz önünde bulundurulduğunda, sinonim "bağırsakderi ekseni”, bu makalenin yazarı çalışmanın amacı doğrultusunda bağırsak restorasyonu sayesinde kanin atopik dermatitis (KAD) hastalığının hafifletileceğini öne sürmektedir. Dört haftalık, açık uçlu, kontrol grubu bulunmayan çalışmaya daha önceden sağaltım görmemiş KAD'li ve sahipli 8 köpek dahil edildi. Değerlendirmede Köpeklerde Atopik Dermatitis Yaygınlığı ve Şiddetine ait İndeks 4. Versiyonu (CADESI-04) skorları, gözlemsel analog skalası (GAS) ve Polycheck in vitro alerjen spesifik testler kullanıldı. Dışkı örnekleri, 4 hafta boyunca günde 2'şer kez uygulanan fekal mikrobiyota transplantasyon (FMT) kapsül sağaltımı öncesi ve sonrası bağırsak mikrobiyotasında meydana gelen değişimleri değerlendirmek üzere çift indeksli tek-aşamalı PZR ve 16S rRNA hedefli metagenomik analizlerine dayandırıldı. Her olguda kaşıntı saptanırken, bu köpeklerin tamamında artan IgE seviyeleri mevcuttu. CADESI skorlarının 28. günde (4-21), 0. gündeki (50-128) çıkış değerlerine oranla azaldığı tespit edildi. Benzer olarak 28. günde belirlenen GAS skorlarının (0-2), önceki değerlere (6-10) göre azaldığı belirlendi. Epidermal bariyer fonksiyonlarına ilişkin olarak epidermal hidrasyon (55-100'e karşı1ık 4-24) ve pH (6-7,8'e karşılık 4,2-5,7) değerleri sırası ile FMT sağaltımı sonrası, öncesine oranla artmıştı. Alfa dağılımı mikrobiyotada hem zenginliğin hem de çeşitliliğin tüm olgularda 28. günde geliştiğini gösterdi. Bunun da ötesinde sağlıklı köpeklerde referans noktası kabul edilen Firmicutes: Bacteroidetes $<8$ oranları tespit edildi. Bu çalışma KAD sağaltımında FMT kapsüllerinin potansiyel yararını destekleyici özelliktedir. Bu KAD’e yönelik güvenilir ve tolere edilebilen sağaltım modeli, bağırsak mikrobiyomunun kompozisyonunu, dahil edilen 8 köpekte de sağlık durumuna göre kaydırarak değiştirmiştir.

Anahtar sözcükler: Atopik dermatit, fekal mikrobiyota transplantasyonu, köpek. 


\section{Introduction}

The gastrointestinal system of dogs has long been known to be colonized by complex members of microorganisms, namely microbiome (26). Gut microbiota is beneficial for the host, pivotal as a defensive barrier against enteropathogens, modulating the immune system along with other relevant advantages $(15,27)$, in which alterations in its composition have been associated with acute/ and chronic gastrointestinal disorders in dogs $(14,20)$. As atopic dermatitis (AD) has been linked with gut microbiota; in which alteration in $\mathrm{AD}$ microbiota composition with the absence/depletion of selected bacterial species (24), or diminished biodiversity of the gut microbiome in one-month-old infants caused AD (1). Antibacterial therapy has been linked to elevated risk of $\mathrm{AD}$ in humans (28), probably associated with intestinal microbiota alterations. Given those data, briefly reflect participation of the gut microbiome within the pathogenesis of $\mathrm{AD}$, through stimulation and drilling of immune cells (11).

Given changes regarding gut microbiota linked to several diorders, manoeuvre for restoration or optimization of the microbiota might involve fecal microbiota transplantation (FMT), briefly denoted fecal material obtained from a healthy donor (age matched, preferably) to those of administered to diseased case. The latter FMT procedure paid attention in selected study in $\operatorname{dogs}(5,7)$. Satisfactory results were deemed available for gastrointestinal diseases among dogs after FMT treatment $(21,32)$.

The microbiome, with a pivotal role, is deemed one of the major actor for immune system homeostasis. Dysbiosis, denoted as altered composition and functions in gut microbiome, existing in gut and/or skin, posessess intimate association among "gut-skin axis" could act as a factor for development of AD. Therefore it should not be unwise to claim the association of $\mathrm{AD}$ with gut microbiota (GM) composition. Given the limited treatment options reported previously for CAD, it should not be unwise to state for the known facts, long-term risks of immunosuppressive treatment widely preferred elsewhere. There is an unmet need for a safe and efficacious long term and probably nonimmunosuppressive treatment option for canine atopic dermatitis (CAD). The aim of this open-label, noncontrolled study was to elucidate the probable efficacy of a commercially available FMT capsule containing gut restoration system (obtained from healthy subjects with a known microbiota composition) in CAD. The present author's interest was aroused for FMT capsules solely might effectively mitigate inflammation in dogs suffering from CAD. It was further suggested that the FMT mediated anti-infectious, anti-inflammatory, anti-allergic effects might account for the observed pruritus alleviation and relevant clinical signs to those of affected dogs of various ages.

\section{Materials and Methods}

Prior to conduction of the study, the design was clearly detected and detailed, permitting future (warranted) studies. As AD is a compeller (coercive) disease, owners deny/refuse control cases, which resulted in baseline (prior to treatment; like controls)-therapeutical applications (after FMT treatment) matching. This could allow the present author to compare initial values, thereafter post-treatment data, which could be dedicated as self-control cases. The open-label, non-controlled study - enrolled with written owner consent according to standard clinical practice and compared to mean quantified biomarkers with values on two subsequent reevaluations at day 0 and at the end of week 4 , after therapeutical intervention.

Research period / Inclusion criteria: The present study was conducted at the Aydin Adnan Menderes University, Faculty of Veterinary Medicine, Department of Internal Medicine. A total of eight dogs with a history of frequent itching sensation were initially diagnosed with a presumed CAD based on history, clinical findings, cytology, and necessary dermatological examinations. At the beginning of the present research, all dogs were subjected to a food trial with hydrolyzed proteins for at least 2 months. No prior drug administration was evident, which was one of the inclusion criteria. Dogs were excluded if bacterial or fungal infections (based on laboratory diagnostic); ectoparasites (based on, for example; a flea comb, cytology, dermatoscopy, or skin scraping); flea allergy, metabolic or other nonallergic disorders were diagnosed. Complete blood count, routine serum biochemistry panels and endocrine panels were available on days 0 and 28 for all dogs.

Entire physical analysis were performed on days 0, and 28. The Canine Atopic Dermatitis Extent and Severity Index version 4 (CADESI-04) was used to score the clinical findings [for acute (i.e. erythema) and chronic (i.e. lichenification) and other relevant findings such as alopecia, excoriations, and pruritus]. The animal owners were asked to make interpretation for pruritus via a $10 \mathrm{~cm}$ Visual Analog Scale (VAS) involving descriptors similar to another study $(9,13)$. History involved small samples of quesiton aroused for prior interventions.

In vitro allergen detection: Polycheck Canine Allergy Test (Polycheck, Allergy test, Gmbh, Münster, Germany), an vitro test which detects allergen-specific $\operatorname{IgE}$ in $\operatorname{dog}$ serum) was used (30) to detect underlying etiology as previously described (3).

Treatment protocol: Commercially available (Animal Biome Gut Restoration System FMT capsules, 
Animal Biome, Oakland, California, USA) oral FMT capsules were prescribed orally every 12 hours for 1 month.

Microbiome testing: This procedure briefly included i) sample collection (stool sample was collected and stored at $4-8^{\odot}$ at initial referral prior to treatment application into $70 \%$ ethanol tubes achieved within the test kits provided by the company (Animal Biome Gut Restoration System FMT capsules, Animal Biome, Oakland, California, USA), ii) fecal material isolation, DNA extraction and concentration measurement, iii) $16 \mathrm{~S}$ rRNA gene $(505 \mathrm{~F} / 816$ R) generation using one step PCR $(8,22)$, iv) alpha and beta diversity analysis (6) involving $100 \%$ OTUs classified against SILVA reference database (23). All of the procedures were completed at Animal Biome Laboratory at Oakland, USA by experted and specialized researchers.

Corneometric analysis of skin barrier function: Callegari Soft Plus corneometric device (Castello Dei Diritti, Parma, Italy) was used for skin $\mathrm{pH}$ (by use of double cell electrode able to determine 2-12 $\mathrm{pH}$ ranges) and epidermal hydration (measurement principle: capacitive method by use o special probes detecting 0-100 c.u.) status before and after the treatment. Operating conditions involved room temperature in which dogs were kept there 30 minutes prior to examination.

Statistical analysis: Obtained (interpretation) data were deemed available for descriptive statistics, there afterwards median, standart deviation, minimummaximum values were forwarded to tables. Wilcoxon test was chosen for interpretation of statistical alterations among enrolled parameters and $\mathrm{P}<0.05$ was set as significant. Entire analysis were performed by use of SPSS 21.0 (IBM, Chicago, USA) programme.

\section{Results}

Demographic data: Eight dogs at the age of 24 to 119 months, were involved. All dogs were participated, completed the study without any observable side effects related to therapy. History deemed no prior drug application. Endocrine profile were within reference ranges (total t 4 values ranged between $1.1-3.7 \mu \mathrm{g} / \mathrm{dL}$, plasma cortisol levels $2.2-5.4 \mu \mathrm{g} / \mathrm{dL}$ ).

CADESI-04 and VAS pruritus scores: Both CADESI-04 and VAS pruritus scores were declined in all 8 dogs enrolled. The day 0 scores (50-128) belonging to 7 severe and 1 moderate CAD cases, were significantly higher than scores on day 28 (4-21) switching the severity of the disease to mild status. Day 0 VAS pruritus scores were ranging between 5 to 10 , whereas owner VAS pruritus score had decreased, which corresponds to a reduction from "severe itching" to "absent (0) or normal (2)" on day 28 (after completion of treatment) (Figure 1). Six out of 8 FMT capsule treated dogs were not presenting pruritus at second referall, as detected by the present author. No adverse events attributable to the FMT capsule treatment were reported in any of the dogs. All cases were monitored for 18 months after completion of treatment in which no recurrence was observed. Clinical photographs of three selected cases were shown in Figures 2-4, describing before and after treatment records along with gut microbiota changes. CADESI-04 scores to those of classification of atopic dermatitis along with allergen specific Ig E analysis were shown in Table 1. Six out of 8 dogs with AD presented strong $\operatorname{IgE}$ response against Dermatophagoides farinae. Statistical analysis deemed available in Table 2, as shown, presented that there were significant alterations $(\mathrm{P}=0.012)$ for CADESI-04 and VAS scores along with corneometric analysis before and after treatment.

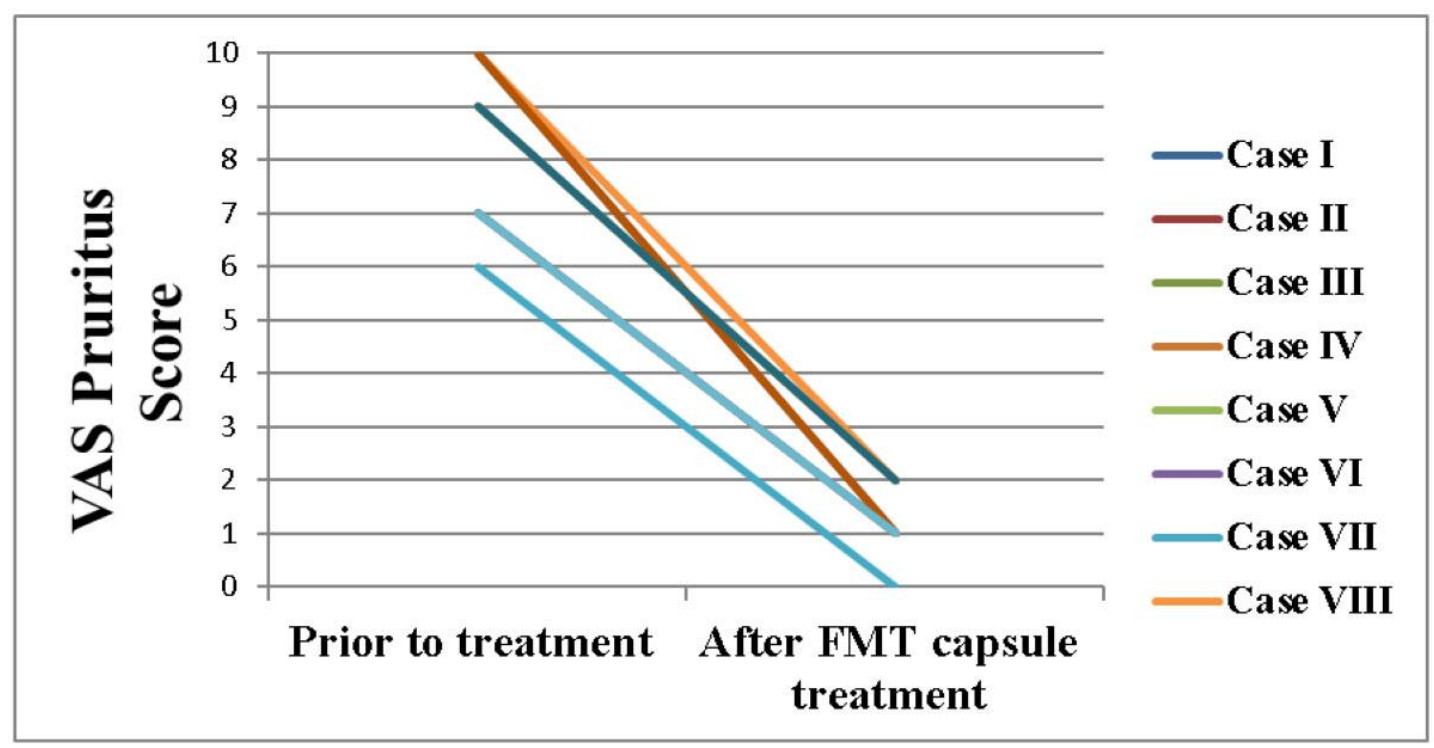

Figure 1. Linear graphic regarding VAS Pruritus Scores for 8 dogs with CAD enrolled in this study (prior to treatment day 0 and after FMT capsule treatment on day 28). 


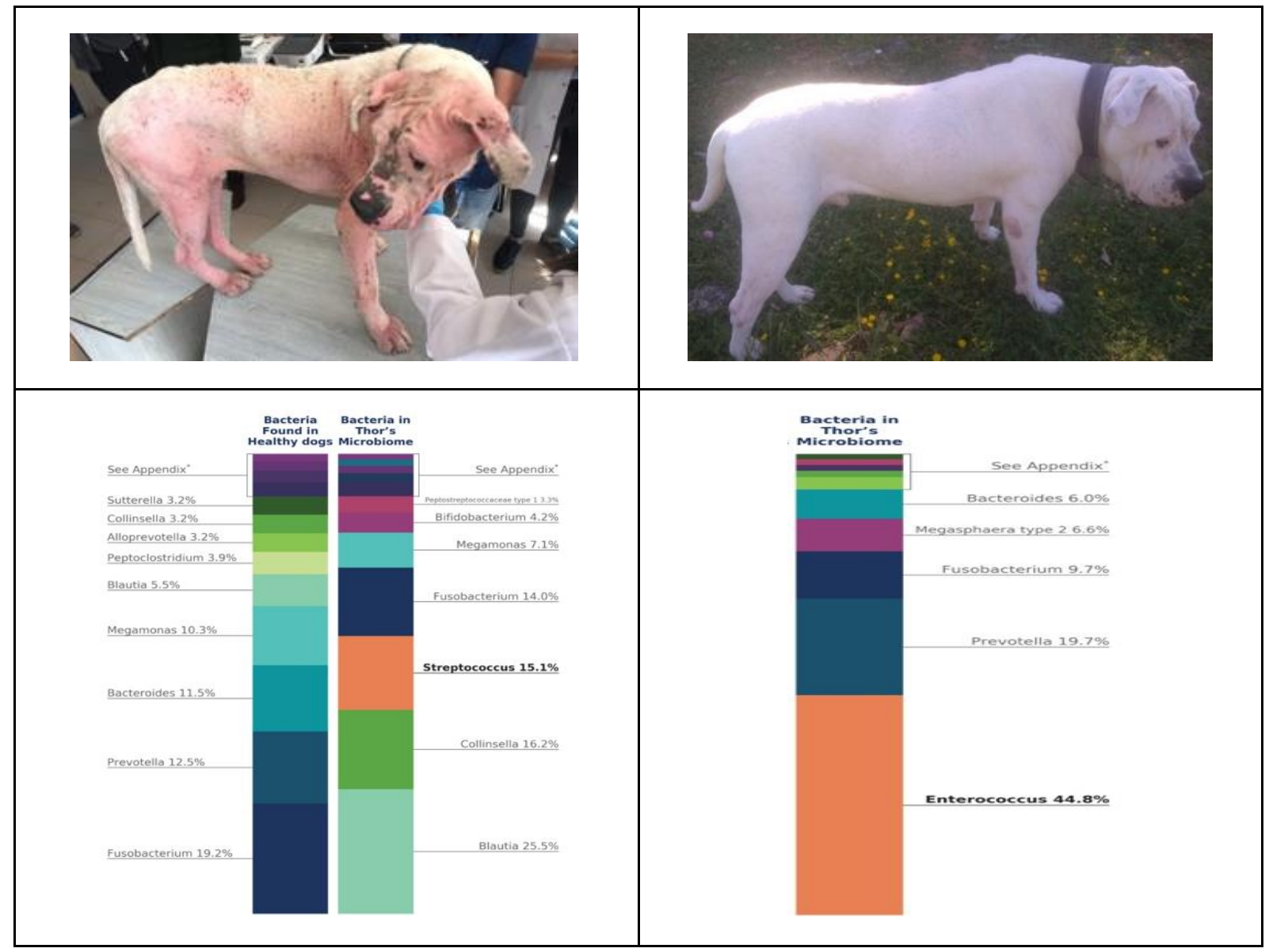

Figure 2. Relative abundaces of gut microbiota belonging to case I, a) before, and b) after completion of FMT capsule treatment. Case 1 before and after treatment showing clinical picture and lesional view along with microbiota analysis. Bar graphic on the left side comperatively showed bacteria found in healthy dogs, to those of on the middle and rigth, before and after treatment, respectively.

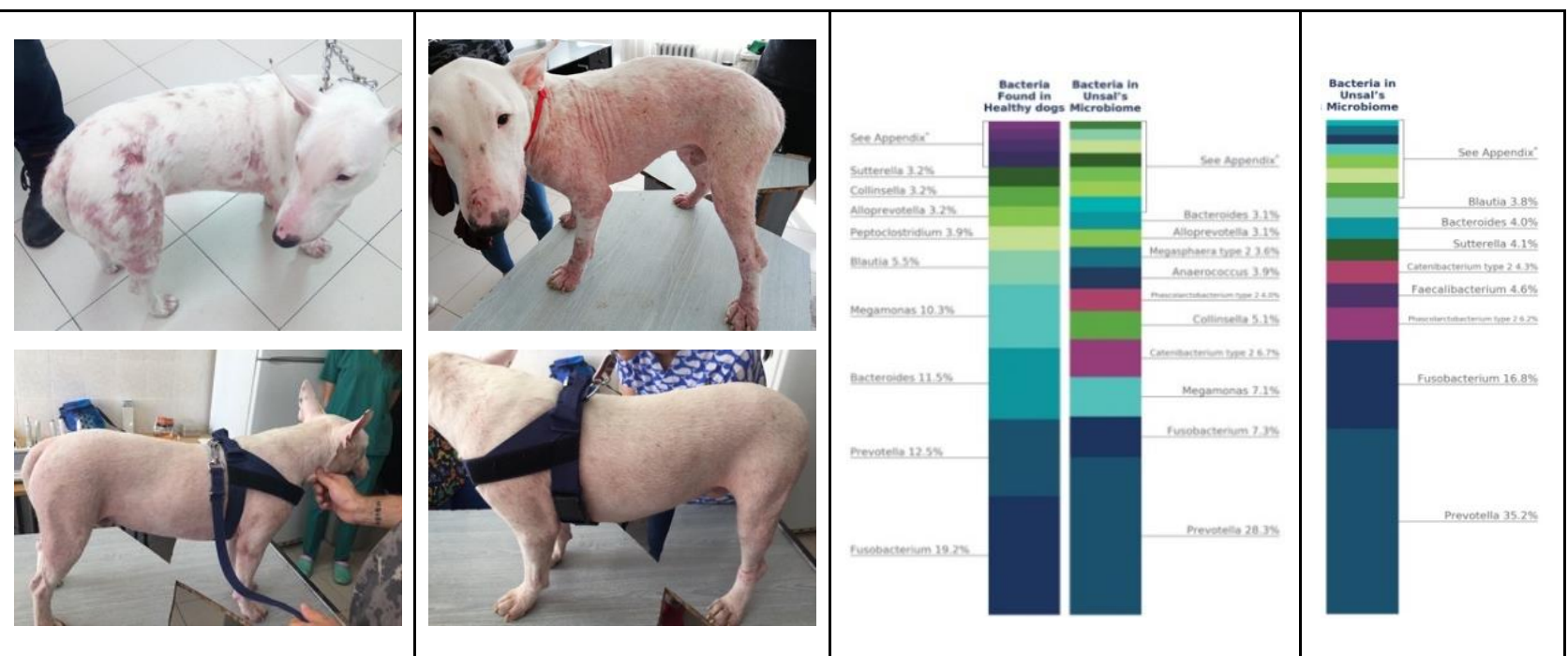

Figure 3. (Case 2) Before and after treatment along with bar graphics showing gut microbiota alterations comperatively (first bar graphic comperatively presents healthy dog microbiota). 


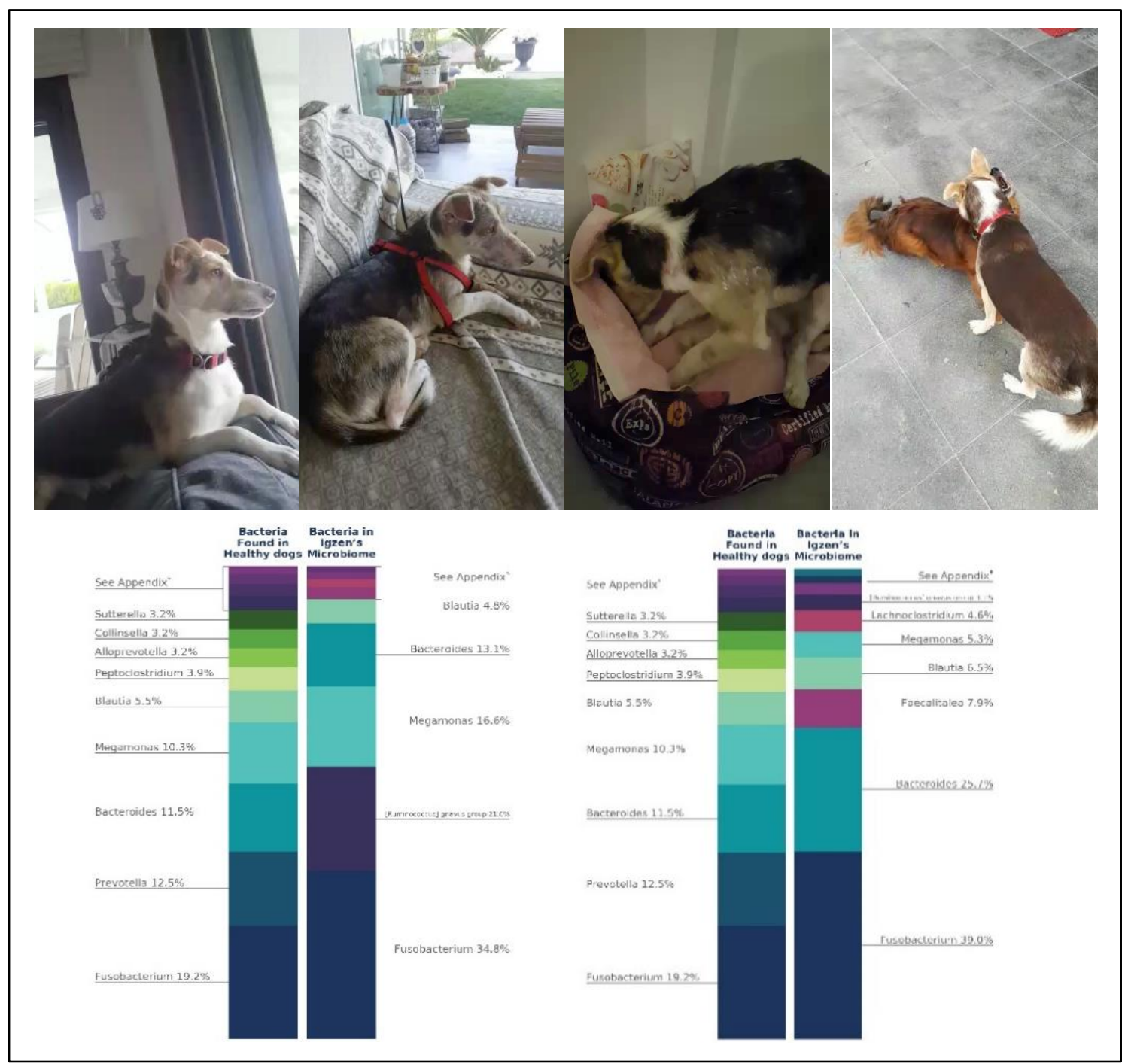

Figure 4. (Case 5) Atopic dog presenting severe pruritus a) prior to treatment, and therafter b, c and d) weeks 2-4, respectively, following fecal microbiota transplantation. Bottom photographs showing gut microbiota alterations comperatively (first bar graphic comperatively presents healthy dog microbiota).

Table 1. Classification, CADESI-04 scores, allergen detection and cornerometric analysis involved within this study apart from microbiota analysis.

\begin{tabular}{|c|c|c|c|c|c|c|c|c|}
\hline \multirow{2}{*}{$\begin{array}{l}\text { Case } \\
\text { no }\end{array}$} & \multirow{2}{*}{$\begin{array}{l}\text { Classification of } \\
\text { CAD }\end{array}$} & \multicolumn{2}{|c|}{ CADESI-04 scores } & \multirow{2}{*}{$\begin{array}{l}\text { Allergen specific in } \\
\text { vitro analysis }\end{array}$} & \multicolumn{2}{|c|}{ Epidermal hydration } & \multicolumn{2}{|c|}{ Epidermal pH } \\
\hline & & bt & aFMT & & $\mathrm{bt}$ & aFMT & bt & aFMT \\
\hline I & Severe & 99 & 12 & D.f., R.p & 4 & 100 & 5 & 7.8 \\
\hline II & Severe & 128 & 14 & D.f., & 8 & 100 & 5.3 & 6.4 \\
\hline III & Severe & 76 & 7 & D.f., R.p & 24 & 100 & 4.2 & 7.0 \\
\hline IV & Moderate & 50 & 21 & D.p. & 12 & 55 & 4.6 & 6.7 \\
\hline V & Severe & 90 & 10 & D.f. & 11 & 90 & 4.4 & 6.0 \\
\hline VI & Severe & 101 & 6 & D.f. & 16 & 76 & 5.0 & 6.2 \\
\hline VII & Severe & 88 & 8 & D.f. & 23 & 80 & 5.7 & 7 \\
\hline VIII & Severe & 79 & 4 & D.f. & 20 & 78 & 4.9 & 6.5 \\
\hline
\end{tabular}

Proposed benchmarks for detecting severity of CAD; 10 (mild), 35 (moderate), 60 (severe atopic dermatitis) - based on skin lesions and CADESI-04 analysis; D.f.: Dermatophagoides farina; D.p.: Dermatophagoides pteronyssinus; R.p: Rye pollen; CAD: Canine Atopic Dermatitis; CADESI-04: Canine Atopic Dermatitis Extent and Severity Index version 4 bt: before treatment aFMT: after treatment. 
Table 2. Statistical analysis of CADESI-04 scores, corneometric analysis and VAS scores shown in Table 1.

\begin{tabular}{cccc}
\hline & $\begin{array}{c}\mathrm{bt} \\
(\text { Median } \pm \text { SD) } \\
(\min -\text { max })\end{array}$ & $\begin{array}{c}\text { aFMT } \\
\text { (Median } \pm \text { SD) } \\
(\text { min-max })\end{array}$ & P value \\
\hline CADESI-04 scores & $89 \pm 22.5$ & $9 \pm 5.4$ & 0.012 \\
Epidermal hydration & $(50-128)$ & $(4-21)$ & 0.012 \\
Epidermal pH & $14 \pm 7.2$ & $85 \pm 15.8$ & 0.012 \\
& $(4-24)$ & $6.6 \pm 0.6$ & $(6-7.8)$ \\
VAS scores & $5.0 \pm 0.5$ & $1 \pm 0.8$ & 0.012 \\
\end{tabular}

bt: before treatment; aFMT: after treatment; CADESI-04: Canine Atopic Dermatitis Extent and Severity Index version 4 VAS: visual analog scale.

Table 3. Alpha diversity was calculated with respect to operational taxonomic unit (OTU) richness, evenness and overall diversity to understand the ecological differences within the CAD in which reference ranges for healthy dogs as follows: overall diversity $2.2+$; richness 38+; evenness: 0.6+ Firmicutes: Bacteroidetes ratio: $<8$ or below (Animal Biome web site).

\begin{tabular}{lllllllll}
\hline Case no & \multicolumn{2}{l}{ Overall diversity } & \multicolumn{2}{c}{ Richness } & \multicolumn{2}{c}{ Evenness } & \multicolumn{2}{c}{ Firmicutes: Bacteroidetes ratio } \\
& bt & aFMT & bt & aFMT & bt & aFMT & bt & aFMT \\
\hline I & 1.94 & 2.32 & 29 & 44 & 0.58 & 0.61 & 126.44 & 0.39 \\
II & 2.44 & 2.95 & 74 & 113 & 0.57 & 0.62 & 1.09 & 0.66 \\
III & 2.51 & 2.6 & 46 & 48 & 0.65 & 0.68 & 0.88 & 0.67 \\
IV & 1.81 & 1.85 & 21 & 24 & 0.57 & 0.61 & 3.85 & 1.35 \\
V & 1.85 & 2.44 & 21 & 40 & 0.61 & 0.45 & 3.82 & 1.34 \\
VI & 1.92 & 2.47 & 62 & 71 & 0.55 & 0.6 & 2.01 & 0.72 \\
VII & 2.02 & 2.95 & 74 & 113 & 0.62 & 0.57 & 1.33 & 0.98 \\
VIII & 1.87 & 2.5 & 34 & 46 & 0.57 & 0.65 & 46.51 & 2.64 \\
\hline
\end{tabular}

bt: before treatment; aFMT: after treatment.

Table 4. Selected OTU analysis and deemed available statistical analysis.

\begin{tabular}{|c|c|c|c|}
\hline & $\begin{array}{c}\text { bt } \\
(\text { Median } \pm \mathrm{SD}) \\
(\min -\mathrm{max})\end{array}$ & $\begin{array}{c}\text { aFMT } \\
(\text { Median } \pm \text { SD) } \\
(\min -\max )\end{array}$ & $\mathrm{P}$ value \\
\hline Overall diversity & $\begin{array}{c}1.9 \pm 0.3 \\
(1.8-2.5)\end{array}$ & $\begin{array}{c}2.5 \pm 0.4 \\
(1.9-3.0)\end{array}$ & 0.012 \\
\hline Richness & $\begin{array}{l}40 \pm 22.4 \\
(21-74)\end{array}$ & $\begin{array}{l}47 \pm 33.8 \\
(24-113)\end{array}$ & 0.012 \\
\hline Evenness & $\begin{array}{l}0.6 \pm 0.03 \\
(0.6-0.7)\end{array}$ & $\begin{array}{c}0.6 \pm 0.1 \\
(0.5-0.7)\end{array}$ & 0.481 \\
\hline Firmicutes: Bacteroidetes ratio & $\begin{array}{c}2.9 \pm 44.5 \\
(0.9-126.4)\end{array}$ & $\begin{array}{c}0.9 \pm 0.7 \\
(0.4-2.6)\end{array}$ & 0.012 \\
\hline
\end{tabular}

bt: before treatment aFMT:after treatment.

Gut microbiota alterations: Alpha diversity was calculated with respect to OTU richness, evenness and overall diversity (Table 3 ) to understand the ecological differences within the CAD using the Shannon indices. To detect differences in OTU composition for CAD cases enrolled in the present study a comparison was made at time point $\mathrm{T}_{0}$ (prior to FMT capsule treatment) and there afterwards with the completion of study at time point T28. The OTU distribution was investigated at the phylum, family and genus levels.
Comperative evaluation of gut microbiota analysis indicated changes in Firmicutes: Bacteroidetes ratio among 8 dogs enrolled before (case I: 126.44 , case II: 1.09, case III: 0.88 , case IV 2.01:3.85, case V:3.82, case VI:2.01, case VII:1.33 and case VIII:3.82) and after completion of treatment $(0.39,0.66,0.67,1.35,1.34,0.72$, 0.98 and 1.34, respectively). Statistical interpretation revealed significant alterations $(\mathrm{P}=0.012)$ for overall diversity, richness and Firmicutes: Bacteroidetes ratio, as shown in Table 4. 
Dogs were monitorized for a total of 18 months after study was completed. None of them were diseased nor recurrence was detected. All were clinically healthy at the time of writing, after 1.5 years were passed following completion of the present study.

\section{Discussion and Conclusion}

Given the microbiome has a pivotal role for immune system homeostasis, alterations in its composition and function, namely dysbiosis both in the skin and the gut, detected to have relationship with CAD. Researches analyzing the influence of microbiome alterations regarding disease process in CAD is awaited. In the present study it was claimed that; i) detecting gut microbiota alterations, and then ii) restoration of gut microbiota within fecal microbiota transplantation (FMT) capsules will significantly decrease both CADESI-04, and the pruritus scores along with maintaining epidermal barrier function after 4 weeks of twice-daily treatment. Available evidence, as proved, in this study showed that FMT capsule therapy via oral route presented clinical cure for $\mathrm{CAD}$, at least for the study duration for 1 month, thereafter 1.5 years monitorization period. Regarding alterations detected within VAS and CADESI-04 scores, FMT capsule therapy resulted in anti-pruritic efficacy and clinical cure was evident to those of all dogs treated, accompanied by withdrawal of clinical signs. All 8 dogs were stable, without appearent itching behaviour, as was in correlation with CADESI-04 scores. Furthermore, a marked correlation was evident for CADESI-04 and pruritus scores, indicating that the FMT capsules resulted with clinical remission might be attributed to i) restoration of gut microbiota, swifting disbiosis (17) to eubiosis, ii) anti-inflammatory effects of probiotics (useful bacteria included in the FMT capsules used, iii) probable impairment of intestinal mucosal barrier (which is involved within the pathogenesis of atopic dermatitis) (17, $18,25)$ and is probably due to suppression of small intestinal bacterial overgrowth $(12,16)$ that has been linked to skin conditions (4). Possible explanation of the relationship between SIBO and skin lesions might be dedicated to damage to gut associated lymphoid tissue, altered lipid metabolism (because of intraluminal bacteria), immune system, elevated intestinal permeability, nutritional insufficiency, systemic extension of lipolysaccharide causing injury against epidermal barrier $(12,16)$. This may be a foremost factor also within the present study. Altough the precise pathogenesis regarding the communication among gut (microbiota) and skin remains unclear, gut-skin association, namely gutskin axis, has been associated with several different dermatoses along with AD (2). A preliminary conclusion should be dedicated to AD linked to gut disbiosis and elevated intestinal permeability (10). Thus, restoration of gut microbiota in atopic dogs to those of involved in this study via FMT capsules achieved orally resulted in clinical remission, could support the obtained evidence.

16S rRNA microbiome testing presented alterations in Firmicutes: Bacteroidetes ratio among 8 dogs enrolled before (0.88-126.44) and after completion of treatment (0.39-3.35). Alterations among Firmicutes: Bacteroidetes ratio (speficically in case 1 from 126.44 to 0.39 , respectively through day 0 to 28 , might be briefly explained with possible gut restoration and available diversity. All 8 dogs with CAD showed elevated levels of Firmicutes at phylum level. Increased abundance of Firmicutes might indicate exacerbation of CAD symptoms (prior to treatment), in which decreased Firmicutes: Bacteroidetes ratio (and thereof clinical recovery) among all dogs treated with FMT capsules on day 28 supported this explanation involving dogs enrolled in this study. Statistical significance $(\mathrm{P}=0.012)$ for overall diversity, richness and Firmicutes: Bacteroidetes ratio, (Table 4) were evident, briefly/additionaly supportive proof of FMT treatment in the present study.

In the present study, the response to FMT capsules for restoration of gut microbiota (as detected by prior to after analysis of $16 \mathrm{~S}$ rRNA PCR) was rapid, with the majority of the clinical improvement evident by week 3 . CADESI-04 scores tended to qucikly improve thereafter in almost all of the cases enrolled. Significant alterations $(\mathrm{P}=0.012)$ for CADESI-04 and VAS scores along with corneometric analysis before and after treatment (Table 2) all detected were in favour of FMT treatment modality in the present study. Given the identified role of microbiota in the alterations of several disease processes, there is no doubt that an imbalance of microbiota has a well known connection with gastrointestinal and skin disorders. As an innovative treatment option, as was performed int this study, FMT might be capable of restorating disturbed microbiota evidenced by several different reports and clinical trials. Taking into account emerging data on the probable otential clinical applicability of FMT beyond CDI in both gastrointestinal and nongastrointestinal conditions.

Age related alterations (namely transition) is evident in dogs in which beneficial bacteria species in host animals might present variations (based on the host) (19). In the present study dogs with $\mathrm{AD}$ were aged between 24 to 119 months, in which were classified as young to middle aged (young dogs: 2 years- and aged dogs were greater than 10 years old) as was determined previously (19). A question might arouse regarding FMT capsules composition and age of diseased dogs. As FMT capsules were purchased from a commercial company at USA, they claimed that the donors for FMT capsules involved dogs 
monitorized for health, age, microbiome composition (based on DNA testing) and other relevant biomarkers, suggesting that age matched treatment (individualized FMT capsules) might be available.

From another point of view, based on "gut-brain-skin axis" gastroenterology and dermatology should met each other at the crossroads (29). Following completion of the present study, it was clearly suggested that dermatological disease should be investigated and an interpretation must be based on underlying gastroenterological issues, as was supported with all cases enrolled. To the present authors knowledge' dogs participate as a role model for atopic diseas in humanbeing, in which obtained results and FMT probably participate as candidate therapeutical armamentarium. As a novel treatment modality FMT capsules might mitigate AD among dogs, in which supported a balanced bridge between the purpose and the results of the present study.

In conclusion, treatment with FMT capsules is an easy and relatively/reasonably priced and resulted within complete efficacy and toleration in 8 dogs with AD. Instead of immunosuppressive treatment, this gut restoration system with potential immunomodulatory, anti-inflammatory and antioxidant formulation may be more likely to benefit by substituting this treatment modality. Further studies are warranted with a larger cases, possessing controlled propective research which should support the present findings. This commercially available FMT gut restoration system product has been licensed in the United States of America for usage in cats and dogs for different diseases. The present author has competing interest within this subject, aimed at performing novel projects focusing on 'gut-brain-skin axis' and gut/skin microbiota.

\section{Acknowledgement}

This research received no grant from any funding agency/sector. The author would like to thank RDA Group, Istanbul for purchasing test samples.

\section{Financial Support}

This research received no grant from any funding agency/sector.

\section{Ethical Statement}

This study was approved by the Aydin Adnan Menderes University Animal Experiments Local Ethics Committee HADYEK with no: (64583101/2019/022).

\section{Conflict of Interest}

I have competing interest to declare, in which development of biomarkers (via projects, $\mathrm{PhD}$ studies etc.), microbiome analysis, nutraceutical and functional food (investment and development fields), probiotics (29), synbiotics and "fecal microbiota transplantation capsule (fecal-oral) treatment" are under my arousing attention.

\section{References}

1. Abrahamsson TR, Jakobsson HE, Andersson AF, et al (2012): Low diversity of the gut microbiota in infants with atopic eczema. J Allergy Clin Immunol, 129, 434-440.

2. Ali IA, Foolad N, Sivamani RK (2014): Considering the Gut-Skin Axis for Dermatological Diseases. Austin J Dermatolog, 1, 1024-1025.

3. Bizikova P, Santoro D, Marsella R, et al (2015): Clinical and histological manifestations of canine atopic dermatitis. Vet Dermatol, 26, 79-24.

4. Bowe WP, Logan AC (2011): Acne vulgaris, probiotics and the gut-brain-skin axis-back to the future? Gut Pathog, 3, 1 .

5. Burton EN, O'Connor E, Ericsson AC, et al (2016): Evaluation of fecal microbiota transfer as treatment for postweaning diarrhea in research-colony puppies. J Am Assoc Lab Anim Sci, 55, 582-587.

6. Callahan BJ, McMurdie PJ, Rosen MJ, et al (2016): DADA2: High-resolution sample inference from Illumina amplicon data. Nat Methods, 13, 581-583.

7. Chaitman J, Jergens AE, Gaschen F, et al (2016): Commentary on key aspects of fecal microbiota transplantation in small animal practice. Vet Med (Auckl), 7, 71-74.

8. Comeau AM, Douglas GM, Langille MG (2017): Microbiome helper: a custom and streamlined workflow for microbiome research. mSystems, 2, 127-116.

9. Cosgrove SB, Wren JA, Cleaver DM, et al (2013): A blinded, randomized, placebo-controlled trial of the efficacy and safety of the J anus kinase inhibitor oclacitinib (Apoquel $\left.{ }^{\circledR}\right)$ in client-owned dogs with atopic dermatitis. Vet Dermatol, 24, 587-597.

10. Craig JM (2016): Atopic dermatitis and the intestinal microbiota in humans and dogs. Vet Med Sci, 2, 95-105.

11. Egawa G, Weninger W (2015): Pathogenesis of atopic dermatitis: a short review. Cogent Biology 1, 1.

12. Guo S, Al-Sadi R, Said HM, et al (2013): Lipopolysaccharide causes an increase in intestinal tight junction permeability in vitro and in vivo by inducing enterocyte membrane expression and localization of TLR-4 and CD14. Am J Pathol, 182, 375-387.

13. Hill PB, Lau P, Rybnicek J (2007): Development of an owner-assessed scale to measure the severity of pruritus in dogs. Vet Dermatol, 18, 301-308.

14. Honneffer JB, Minamoto Y, Suchodolski JS (2014): Microbiota alterations in acute and chronic gastrointestinal inflammation of cats and dogs. WJG, 20, 16489-16497.

15. Karst SM (2016): The influence of commensal bacteria on infection with enteric viruses. Nat Rev Microbiol, 14, 197204.

16. Kell DB, Pretorius E (2015): On the translocation of bacteria and their lipopolysaccharides between blood and peripheral locations in chronic, inflammatory diseases: the 
central roles of LPS and LPS-induced cell death. Integr Biol, 7, 1339-1377.

17. Majamaa H, Isolauri E (1996): Evaluation of the gut mисоsal barrier: evidence for increased antigen transfer in children with atopic eczema. J Allergy Clin Immunol, 97, 985-990.

18. Marsella R, Olivry T, Carlotti DN (2011): International Task Force on Canine Atopic Dermatitis. Current evidence of skin barrier dysfunction in human and canine atopic dermatitis. Vet Dermatol, 22, 239-248.

19. Masuoka H, Shimada K, Kiyosue-Yasuda T, et al (2017): Transition of the intestinal microbiota of dogs with age. Biosci Microbiota Food Health, 36, 27-31.

20. Minamoto Y, Dhanani N, Markel ME, et al (2014): Prevalence of Clostridium perfringens, Clostridium perfringens enterotoxin and dysbiosis in fecal samples of dogs with diarrhea. Vet Microbiol, 174, 463-473.

21. Pereira GQ, Gomes LA, Santos IS, et al (2018): Fecal microbiota transplantation in puppies with canine parvovirus infection. J Vet Intern Med, 32, 707-711.

22. Pichler R, Fritz J, Tulchiner G, et al (2018): Increased accuracy of a novel mRNA-based urine test for bladder cancer surveillance. BJU International, 121, 29-37.

23. Quast S, Berger A, Eberle J (2013): ROS-dependent phosphorylation of Bax by wortmannin sensitizes melanoma cells for TRAIL-induced apoptosis. Cell Death Dis, 4, 839839.

24. Reddel, S, Del Chierico F, Quagliariello A, et al (2019): Gut microbiota profile in children affected by atopic dermatitis and evaluation of intestinal persistence of a probiotic mixture. Sci Rep, 9, 4996.
25. Rosenfeldt EJ, Linden KG (2004): Degradation of endocrine disrupting chemicals bisphenol A, ethinyl estradiol, and estradiol during UV photolysis and advanced oxidation processes. Environ Sci Technol, 38, 5476-5483.

26. Suchodolski JS (2016): Diagnosis and interpretation of intestinal dysbiosis in dogs and cats. Vet J, 215, 30-37.

27. Sunvold GD, Fahey GC Jr, Merchen NR, et al (1995): Dietary fiber for dogs. IV. In vitro fermentation of selected fiber sources by dog fecal inoculum and in vivo digestion and metabolism of fiber-supplemented diets. J Anim Sci, 73, 1099-1109.

28. Tsakok T, McKeever TM, Yeo L, et al (2013): Does early life exposure to antibiotics increase the risk of eczema? A systematic review. Br J Dermatology, 169, 983-991.

29. Ural K (2020): Probiotics in Veterinary Internal Medicine: A guide book for probiotic usage and case atlas. 1-200. Atalay Konfeksiyon ve Matbacilık. Ankara.

30. Ural K, Erdoğan H, Gültekin M (2018): Allergen specific IgE determination by in vitro allergy test in head and facial feline dermatitis: A pilot study. Ankara Univ Vet Fak Derg, 65, 379-386.

31. Watanabe S, Narisawa Y, Arase S, et al (2003): Differences in fecal microflora between patients with atopic dermatitis and healthy control subjects. J Allergy Clin Immunol, 111, 587-591.

32. Weese JS, Costa MC, Webb JA (2013): Preliminary Clinical and microbiome assessment of stool transplantation in the dog and cat. Proceedings of the 2013 ACVIM Forum. J Vet Intern Med, 27, 705. 